\title{
Influence of impervious cover determination method of upper Ciliwung watershed on flood warning system level change in Katulampa weir
}

\author{
Niswatin Farika ${ }^{1, *}$, Dwita Sutjiningsih ${ }^{1}$, and Evi Anggraheni ${ }^{1}$ \\ ${ }^{1}$ Civil Engineering Department, Faculty of Engineering, Universitas Indonesia, Depok 16424, Indonesia
}

\begin{abstract}
The Katulampa Weir is a part of Jakarta Flood Early Warning System for the Ciliwung River. The measured water level fluctuation in the Katulampa Weir is affected by the physical condition of the Upper Ciliwung Watershed. In this study, the definition and relevance of the impervious cover determination method based on the Total Impervious Area (TIA) and Effective Impervious Area (EIA) in generating design flood discharge and its effect on the change of flood early warning level in Katulampa Weir will be evaluated. Identification of land use distribution is based on digitized process used combined GIS maps using visual interpretation of high resolution satellite images 2017 . The flood analysis for both methods is applied to the same rain conditions. Evaluation of flood early warning level changes are based on flood discharge simulated results and rating curve discharge in the Katulampa Weir. The simulation by WinTR-20 gives that maximum discharge using TIA method is $150 \mathrm{~m}^{3} / \mathrm{s}$ and EIA method $139.5 \mathrm{~m} / \mathrm{s}$. There is no significant difference between and both are classified as the same level of flood early warning system level, which is on stage 3 . However, for large watersheds, it takes much effort to identify and digitize an effective impervious area.
\end{abstract}

\section{Introduction}

The Katulampa Weir is part of the flood early warning system from Ciliwung River which will flow into Jakarta. Water level fluctuation measured is affected by physical characteristic of Upper Ciliwung watershed. Ecological condition in Ciliwung watershed is going worse, with decreasing forest land cover from $9.4 \%$ in 2000 to $2.3 \%$ in 2010 , or environmental degradation rate of $7.14 \%$ in the last decade [1].

Impervious cover is defined as a land cover that prevents infiltration of water from the surface into the soil [2]. Some study suggest that impervious cover is one of the main indicators of water quality in a watershed. Water quality will start to decrease if more than $10 \%$ of watershed area is impervious [3]. Urbanization has caused in increasing number of impervious cover (road, parking lot, roof, pedestrian, etc.) which decreases the number of forest, wetland, and other open space parts which infiltrates rainfall [3].

Recent study shows that surface runoff in a watershed can be better described by Effective Impervious Area (EIA) than TIA [4]. The method usually used to determine the level of imperviousness is based on the total area of impervious area (TIA). Total Impervious Area (TIA) is an area measurement which resists infiltration of rainfall into the soil, while Effective Impervious Area (EIA) is part of TIA which has hydraulic connection straight into drainage system [5]. Another parameter related to impervious area is effective impervious area (EIA) which is the portion of TIA that is directly connected to the drainage system. Definition of hydraulically connected is water that falls on impervious cover will travel through impervious lane into the inlet of drainage channel [6].

Referring to the result of the study, this research will predict the flood discharge in Katulampa Weir using the information of imperviousness determined based on TIA and EIA method. Further predictions of the proposed hydrograph flood calculation results are used to identify differences in flood levels in the flood early warning system in the Katulampa Weir.

\section{Research Methodology}

Data analysis process in order to obtain research goals are as follows:

- Identification of land use distribution based on GIS map from visual interpretation and high-resolution satellite image Pleaides and World View 2

- Calculation of imperviousness using TIA and EIA

- Calculation of weighted Curve Number $(\mathrm{CN})$ in subwatersheds to be used to calculate flood discharge

- Evaluation of flood discharge with water level based on rating curve in Katulampa Weir to determine flood status

\subsection{Study Area}

The research was conducted in Upper Ciliwung Watershed. The upstream part of Ciliwung River is located at Gunung Gede-Pangrango which then flows through Bogor Regency, Bogor Municipality, Depok City and empties into Jakarta Bay. The water level fluctuation in the Ciliwung River is affected by the physical condition of the Upper Ciliwung Watershed. 

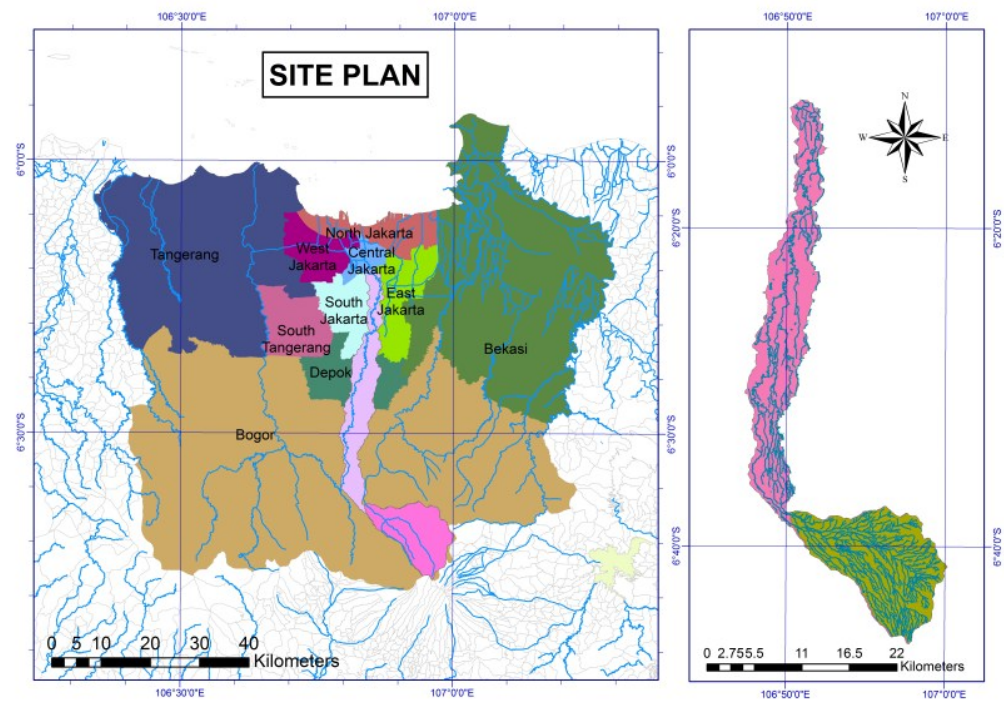

Fig. 1. Study Area

\subsection{Data Requirement}

Required data include rainfall data, water level data, soil type, DEM/topography, land use, building plot, road network and river network. Rainfall data is used as input model representing the research area of Gadog Station, Cilember Station and Gunung Mas Station. The runoff analysis of the spatial distribution difference of spatial impervious area is applied to the same rain conditions. The water level data in the Katulampa Dam is used for model calibration/validation purposes.

Delineated watershed of Upper Ciliwung includes the area of 15.075 hectare started from Tugu Village Puncak to Katulampa Weir located in 3 sub-district administrations of Cisarua, Megamendung and Ciawi.

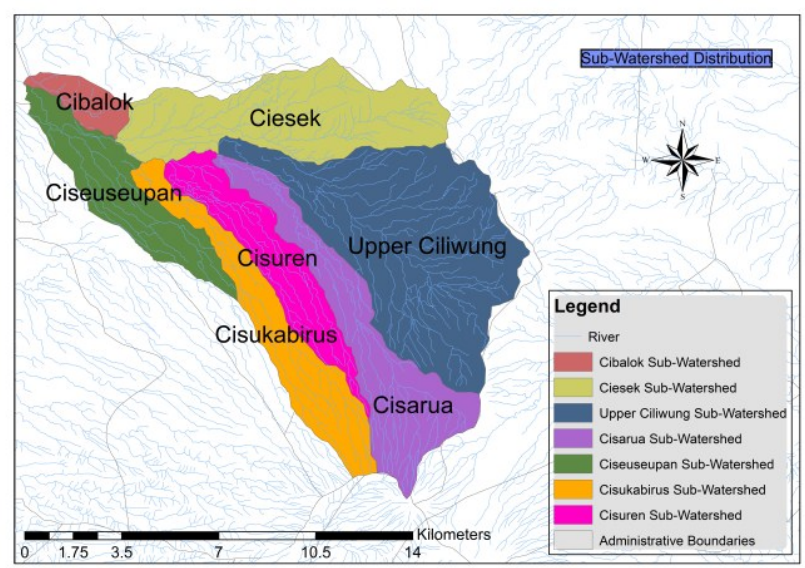

Fig. 2. Upper Ciliwung Watershed

Land use distribution in Upper Ciliwung Watershed using 2017 data obtained from BBWS Ciliwung Cisadane. The Ciliwung River Watershed delineation process into Upper Ciliwung Sub-Watershed uses ArcGis Application Version 10.1 with an Earth Range Map of Indonesia (RBI) data source containing contour, high point, river network, administration and road network from Geospatial Information Agency (BIG), Cibinong Bogor.
Table 1. Sub-watershed Division

\begin{tabular}{l|lr}
\hline No & Sub-watershed & Area(hectare) \\
\hline 1 & Ciliwung Hulu & $4.799,97$ \\
2 & Cisarua & $2.293,75$ \\
3 & Cisuren & 1.483 \\
4 & Cisukabirus & $1.741,97$ \\
5 & Ciesek & 2.804 \\
6 & Ciseuseupan & $1.523,61$ \\
7 & Cibalok & 429,66 \\
\hline
\end{tabular}

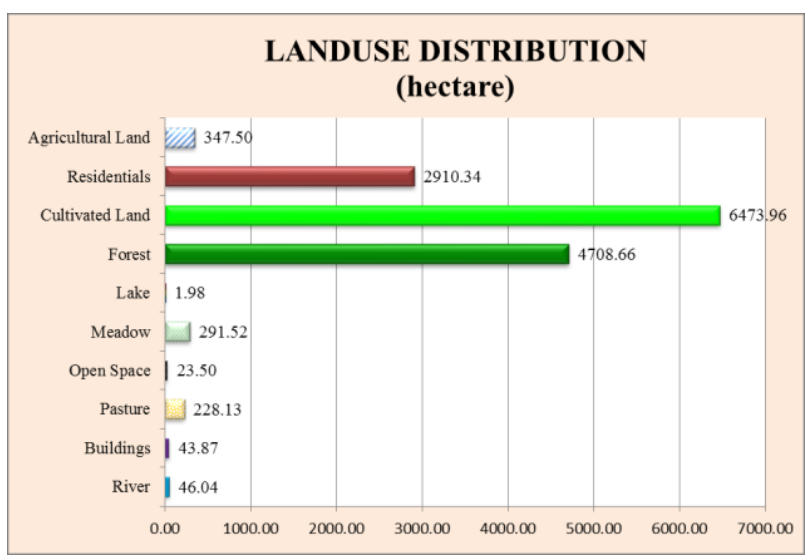

Fig. 3. Land Use Distribution of Upper Ciliwung Watershed

\subsection{Katulampa Weir Technical Data}

Geographically, Katulampa Weir is located in $6^{\circ} 37^{\prime} 07^{\prime}$ 'LS dan $106^{\circ} 47^{\prime} 38^{\prime \prime}$ 'BT. Ciliwung discharge in Katulampa Weir be known with water level reading which will be converted using rating curve.

Table 2. Katulampa Weir Warning Level Criteria

\begin{tabular}{l|c|c|c|c}
\hline \multirow{2}{*}{ Level } & \multicolumn{2}{|c|}{ Water Level Limit $(\mathrm{cm})$} & \multicolumn{2}{c}{ Discharge Limit (cms) } \\
\cline { 2 - 5 } & Upper & Lower & Upper & Lower \\
\hline I & 200 & - & 441.98 & - \\
\hline II & 150 & 199 & 276.25 & 438.48 \\
\hline III & 80 & 149 & 90.05 & 273.23 \\
\hline IV & 0 & 79 & 0 & 87.85 \\
\hline
\end{tabular}

Source : $B P B D$, Jakarta Province

\footnotetext{
Corresponding author: niz ika@yahoo.co.id
} 
Table 3. Rooftops and Road Network Area Distribution

\begin{tabular}{|c|c|c|c|c|c|c|c|c|}
\hline \multirow[t]{2}{*}{ No } & \multirow[t]{2}{*}{ Sub-Watershed } & \multirow[t]{2}{*}{$\begin{array}{c}\text { Area } \\
\text { (Hektar) }\end{array}$} & \multicolumn{2}{|c|}{ Rooftops Area } & \multicolumn{2}{|c|}{$\begin{array}{l}\text { Road Network } \\
\text { Area }\end{array}$} & \multicolumn{2}{|c|}{$\begin{array}{c}\text { Total Rooftops \& } \\
\text { Road Network } \\
\text { Area (EIA) }\end{array}$} \\
\hline & & & (Hektar) & $(\%)$ & (Hektar) & $(\%)$ & (Hektar) & $(\%)$ \\
\hline 1 & Ciliwung Hulu & 479897 & 251.70 & $25.80 \%$ & 109.56 & $32.84 \%$ & 361.26 & $27.59 \%$ \\
\hline 2 & Cisarua & 229375 & 94.18 & $9.65 \%$ & 43.61 & $13.07 \%$ & 137.79 & $10.52 \%$ \\
\hline 3 & Cisuren & 280437 & 64.08 & $6.57 \%$ & 34.86 & $10.45 \%$ & 98.94 & $7.56 \%$ \\
\hline 4 & Cisukabirus & 148337 & 70.32 & $7.21 \%$ & 16.07 & $4.82 \%$ & 86.38 & $6.60 \%$ \\
\hline 5 & Ciesek & 174197 & 190.37 & $19.51 \%$ & 60.40 & $18.11 \%$ & 250.78 & $19.15 \%$ \\
\hline 6 & Ciseuseupan & 152361 & 277.24 & $28.42 \%$ & 55.16 & $16.53 \%$ & 332.40 & $25.39 \%$ \\
\hline 7 & Cibalok & 42966 & 27.78 & $2.85 \%$ & 13.95 & $4.18 \%$ & 41.73 & $3.19 \%$ \\
\hline \multicolumn{2}{|c|}{ DAS Ciliwung Hulu } & 1507570 & 975.67 & & 333.60 & & 1309.27 & \\
\hline
\end{tabular}

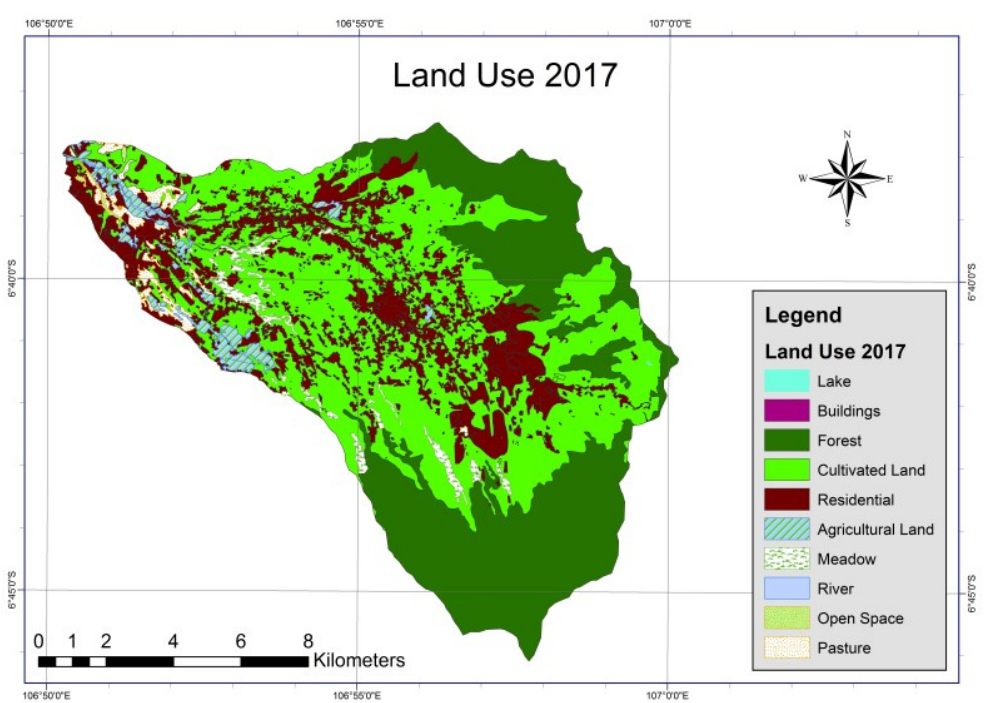

Fig. 4 Land Use of Upper Ciliwung Watershed 2017

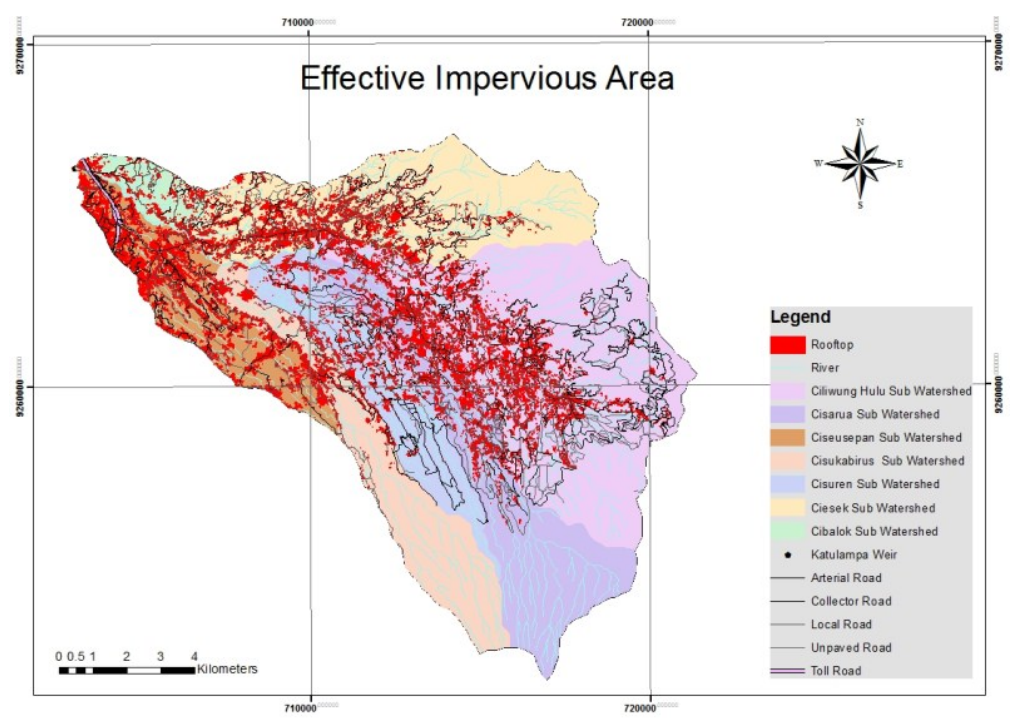

Fig. 5 Effective Impervious Area as the number of rooftops and road network

\subsection{Impervious Area Determination}

The determination of TIA in this study is based on land use or zoning mapping used by the Indonesian Geospatial Information Agency. Meanwhile, to obtain an effective impervious area based on digitized process used combined GIS maps and visual interpretation results from high resolution satellite images of World
View 2 in 2017 with a scale of 1: 25.000 obtained from the Department of Geography Faculty of Mathematics and Natural Sciences University of Indonesia.

The effective impervious area determined based on recognized rooftops and road-network. Table 3 shows distribution of effective impervious area as the number of rooftops and road network areas in each sub-

Corresponding author: niz ika@yahoo.co.id 
watershed. The Effective Impervious Area of Upper Ciliwung watershed is shown in Figure 5.

\subsection{Model Simulation and Calibration}

Hydrological modelling in this study is use WinTR-20 v. 3.20. WinTR-20 adopts work principal of SCS-CN model to calculate direct runoff. $\mathrm{CN}$ table refers to method used by United States Department of Agriculture (Chow, 1988). Flood discharge analysis with two scenarios: 1) TIA parameter, and 2) EIA parameter. Simulation of flood hydrograph based on rainfall event on April 13 ${ }^{\text {rd }}, 2017$ and water level reading in Katulampa Weir at the same time. The method used for calibration and validation are determination coefficient $\left(\mathrm{R}^{2}\right)$ and Nash-Sutcliffe (NSE).

\section{Result and Discussion}

Rainfall intensity based on Thiessen method on 2017 was $45.4 \mathrm{~mm} /$ day with hypothetical distribution following Wanny Model distribution starts at noon and lasting in 4 hours. Table 4 summarizes information needed to simulate flood hydrograph using WinTR-20.

Tabel 4. Input Data for WinTr-20 Simulation Model

\begin{tabular}{l|lccccc}
\hline No & Sub-watershed & $L$ & $T c$ & \multicolumn{2}{c}{$C N_{\text {weighted }}$} \\
\cline { 5 - 6 } & & $(\mathrm{km})$ & $(\mathrm{hr})$ & $T I A$ & $E I A$ \\
\hline 1 & Ciliwung Hulu & 15.49 & 1.56 & 73.84 & 75.30 \\
2 & Cisarua & 17.45 & 1.32 & 75.32 & 76.86 \\
3 & Cisuren & 15.01 & 1.42 & 71.93 & 72.64 \\
4 & Cisukabirus & 15.75 & 1.33 & 80.29 & 80.71 \\
5 & Ciesek & 14.53 & 1.36 & 71.87 & 72.35 \\
6 & Ciseuseupan & 12.26 & 1.58 & 81.36 & 81.70 \\
7 & Cibalok & 2.96 & 0.42 & 77.77 & 78.09 \\
\hline
\end{tabular}

Simulation result provided in Figure 5 as flood hydrograph. Table 5 summarizes comparation of parameters, which consist of peak flow (QP), time to peak (TP), and flood duration (TB). It should be noted that $\mathrm{Q}_{\text {observed }}$ is used as measured discharge data, while $\mathrm{Q}_{1}$ is used for discharge approximation using TIA method, and $\mathrm{Q}_{2}$ used using EIA method.

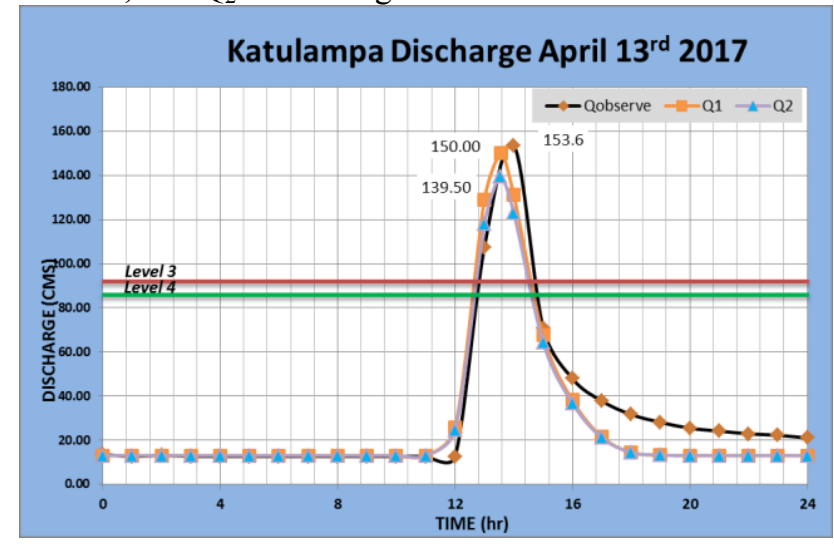

Fig. 6 Flood Hydrograph Simulation

Tabel 5. Summarized Flood Hydrograph Parameter

\begin{tabular}{c|c|c|c|c|c|c|c|c|c}
\hline \multirow{2}{*}{$\begin{array}{c}\text { Observe } \\
\text { Point }\end{array}$} & \multicolumn{3}{|c|}{$\begin{array}{c}\text { Peak Flow } \\
\text { Discharge } \\
\text { (cms) }\end{array}$} & \multicolumn{4}{c|}{$\begin{array}{c}\text { Time Peak } \\
\text { (hr) }\end{array}$} & \multicolumn{3}{c}{$\begin{array}{c}\text { Flood } \\
\text { Duration } \\
\text { (hr) }\end{array}$} \\
\cline { 2 - 11 } & $Q_{\text {obs }}$ & $Q_{1}$ & $Q_{2}$ & $Q_{\text {obs }}$ & $Q_{1}$ & $Q_{2}$ & $Q_{\text {obs }}$ & $\mathrm{Q}_{1}$ & $\mathrm{Q}_{2}$ \\
\hline $\begin{array}{c}\text { Katulampa } \\
\text { Weir }\end{array}$ & 153.6 & 150 & 139.5 & 2 & 1.56 & 1.54 & 11 & 8 & 8 \\
\hline
\end{tabular}

The model hydrograph generally has a slightly different value than the observed hydrograph. The peak flow model between TIA parameters and measured discharge has a difference of $3.6 \mathrm{~m}^{3} / \mathrm{s}$. This condition is different from the result of an EIA parameter that is smaller than the measured discharge of $14.1 \mathrm{~m}^{3} / \mathrm{s}$. However both methods have peak time (Tp) which is smaller than observation.

The coefficient value of determination $\mathrm{R}^{2}$ and NSE value for TIA method is 0.973 and 0.925 and for EIA method is 0.971 and 0.924 . Thus the watershed simulation results can be said good results category.

\section{Conclusion}

Calculation using WinTR-20 gives the result that maximum discharge which is possible to obtained using TIA method is $150 \mathrm{~m}^{3} / \mathrm{s}$ with water level reading of 196 $\mathrm{cm}$. Compared with EIA method which produces the discharge of $139.5 \mathrm{~m}^{3} / \mathrm{s}$ with water level reading of $182.5 \mathrm{~cm}$. This study only performs simulation based on one rain event so that further study is needed to see the effect of both methods on design flood discharge.

The result shows that both methods are acceptable. There is no significant difference between and both are classified as the same level of flood early warning system level, which is on stage 3 . However, for large watersheds, it takes much effort to identify and digitize an effective impervious area.

This work was supported by Universitas Indonesia through the PITTA 2018 under grant No.2422/UN2.R3.1/HKP.05.00/2018, which is greatly appreciated. The author would like to thank the anonymous reviewers for their valuable comments as well.

\section{References}

1. W.Y. Bhakti, Prediksi Laju Erosi Potensial Dan Laju Timbulan Sampah Potensial Pada Luasan Penutup Lahan Kedap Air (Studi Kasus Das Ciliwung), Universitas Indonesia, Depok, 2014.

2. M. Zalewski, Ecohydrology-The Use of Ecologycal and Hydrologycal Processes For Sustainable Management Of Water Resources, Warsave, Hydrological Sciences Journal Vol. 47.

3. Chithra S.V., Dr. M.V. Harindranathan Nair, Amarnath A and Anjana N.S, Impacts of Impervious Surfaces on the Environment, International Journal of Engineering Science Invention, ISSN (Online): 2319 - 6734, ISSN (Print): 2319 - 6726 Volume 4 Issue 5, May 2015.

4. A. Ebrahimian [et al.], Determination Of Effective Impervious Area In Urban Watershed, Minnesota Department of Transportation, Minneapolis, 2015.

5. S.S Nalini and P. Sreeja, Impact of Total and Effective Imperviousness on Runoff Prediction, Springer International Publishing Switzerland, 2016.

6. W.S Han and S.J. Burian, Determining Effective Impervious Area for Urban Hydrologic Modeling, Journal of Hydrologic Engineering, Volume 14, Issue 2, February 2009. 